\title{
KOMPETENSI KOGNITIF PEMBELAJARAN APRESIASI SASTRA DI SEKOLAH DASAR
}

\author{
Elfia Sukma binti Bachtiar dan Ahmad Johari Sihes \\ Fakulti Pendidikan, Universiti Teknologi Malaysia, \\ Skudai-Johor, Malaysia \\ Email: elfiasukma105@gmail.com
}

\section{Submitted :05-05-2016, Reviewed:30-05-2016, Accepted:31-10-2016 http://dx.doi.org/10.22202/JG.2016.v2i1.1395}

\begin{abstract}
Abstrak
Artikel ini bertujuan untuk mendeskripsikan kompetensi kognitif yang perlu dikuasai oleh guru dalam materi apresiasi sastra anak dalam pembelajaran bahasa Indonesia. Penelitian ini menggunakan pendekatan kualitatif. Data diperoleh berdasarkan hasil wawancara semi terstruktur. Data dianalisis menggunakan pendekatan analisis dengan menggunakan analisis kualitatif. Subjek penelitian ini berjumlah dua belas orang, terdiri atas enam orang guru inti SD dan enam orang dosen PGSD UNP. Target dari penelitian ini adalah menghasilkan kerangka kompetensi kognitif yang perlu dikuasai guru dalam materi apresiasi sastra anak dalam pembelajaran bahasa Indonesia di Sekolah Dasar.

Kata-kata kunci: kompetensi kognitif, apresiasi sastra, sekolah dasar

Abstract

This article aims to describe the cognitive competencies that need to be controlled by the teacher in the material appreciation of children's literature in learning Indonesian. This study used a qualitative approach. Data obtained on the basis of semi -structured interviews. Data were analyzed using analysis approach using qualitative analysis. This research subject twelve people, consisting of six core elementary school teachers and six lecturers PGSD UNP. The target of this research is to produce a framework of cognitive competencies that need to be mastered in a matter of appreciation of teachers of children's literature in Indonesian language learning in primary school.
\end{abstract}

Keywords: cognitive competencies, literary apreciation, primary school 


\section{Pendahuluan}

Pembelajaran sastra anak merupakan bagian dari pembelajaran bahasa Indonesia di sekolah dasar. Pembelajaran sastra anak bertujuan mendorong tumbuhnya sikap apresiatif terhadap karya sastra yaitu sikap menghargai dan mencintai karya sastra. Huck, Hepler, dan Hickman (1987) berpendapat bahwa pembelajaran sastra di sekolah dasar harus memberikan pengalaman kepada siswa yang berkontribusi pada: (1) pencarian kesenangan pada buku (discovering delight in books), (2) menginterpretasi bacaan sastra (interpreting literature), (3) mengembangkan kesadaran bersastra (literary awareness), dan (4) mengembangkan kesadaran bersastra (developing apreciation). Untuk itu, siswa harus diakrabkan dengan beragam bentuk sastra anak dan diberi kesempatan memahami, menikmati, dan merespons bacaan sastra anak yang telah mereka baca dengan cara menarik minat mereka.

Menurut Rusyana (2002) tiga kompetensi utama dalam pembelajaran sastra di sekolah, yaitu (1) kemampuan mengapresiasi sastra yang dapat dilakukan melalui kegiatan mendengarkan hasil sastra, menonton hasil sastra, dan membaca hasil sastra berupa puisi, cerita pendek, novel, dan drama; (2) kemampuan berekspresi sastra dilakukan melalui kegiatan melisankan hasil sastra, dan menulis karya cipta sastra berupa puisi, cerita pendek, novel, dan drama; dan (3) kemampuan menelaah hasil sastra yang dapat dilakukan melalui kegiatan menilai hasil sastra, meresensi hasil sastra, dan menganalisis hasil sastra. Pembelajaran sastra ditujukan untuk meningkatkan kemampuan siswa dalam menikmati, menghayati, dan memahami karya sastra serta mengambil hikmat atas nilai-nilai luhur yang terselubung di dalamnya. Pengetahuan tentang sastra hanyalah sebagai penunjang dalam mengapresiasi karya sastra. Kalau pembelajaran sastra sudah dilakukan sesuai dengan pedoman yang ada dalam kurikulum, diharapkan keluhan-keluhan tentang kurang berhasilnya pembelajaran sastra di sekolah dapat berkurang.

Kinayati (2006) dalam kajiannya menyatakan bahwa karya sastra mempunyai kaitan dengan masalahmasalah pendidikan dan pembelajaran. Oleh sebab itu, sangat keliru bila dunia pendidikan selalu menganggap bidang eksakta lebih utama, lebih penting dibandingkan dengan ilmu sosial atau ilmu-ilmu kemanusiaan. Masyarakat memandang karya sastra hanyalah khayalan pengarang yang penuh kebohongan sehingga timbul klasifikasi dan diskriminasi. Padahal karya sastra mempunyai pesona tersendiri bila kita mau membacanya. Karya sastra dapat membukakan mata pembaca untuk mengetahui realitas sosial, politik dan budaya dalam rangka pembinaan moral dan estetika. Dari dulu sampai sekarang pesona karya sastra tidak pernah pudar. Dalam kenyataan, karya sastra boleh dipakai untuk mengembangkan wawasan berpikir bangsa. Karya sastra dapat memberikan pencerahan pada masyarakat modern.

Kecerdasan manusia dapat diperhatikan melalui tiga ranah, yaitu ranah kognitif, psikomotor, dan afektif. Pengembangan ranah kognitif dapat meningkatkan kemampuan berpikir. Secara empiris, kemampuan berpikir guru belum dikembangkan secara optimal. Pengembangan kemampuan kognitif baru dikembangkan sampai pada tingkat analisis, sedangkan kemampuan menilai belum dikembangkan. Hal ini dapat dilihat dari nilai rata-rata hasil Uji Kompetensi Guru (UKG) secara nasional sebesar 42,7 (Kementerian Pendidikan Nasional, 2012).

Kekurangoptimalan pembelajaran sastra anak di sekolah dasar, antara lain 
karena pembelajaran sastra yang dilakukan baru pada tahap pengembangan ranah kognitif dan sedikit ranah psikomotor, sedangkan ranah afektifnya belum dikembangkan secara optimal. Pembelajaran apresiasi sastra harus mengembangkan tiga kompetensi sekaligus, yaitu kompetensi kognitif, afektif, dan psikomotor. Kekurangan dan ketertinggalan pembelajaran sastra di sekolah terlihat pada hasil penelitian yang dilakukan oleh Taufiq Ismail terhadap pengajaran sastra dan mengarang, yang melakukan perbandingan di 13 negara yang menunjukkan bahwa pengajaran sastra dan mengarang di negara Indonesia sampai saat ini masih jauh tertinggal dari negara-negara lain (Ismail, 2000). Untuk itu, perlu adanya usaha untuk mereaktualisasikan pembelajaran sastra di sekolah yang selama ini dianggap belum mencapai sasaran secara optimal.

Permasalahan lainnya dalam pembelajaran sastra di sekolah dasar terletak pada guru. Hal ini tergambar dengan jelas berdasarkan beberapa penemuan dan pendapat, seperti Alwasilah (1994; 1999), Wei (1999), dan Mansour (1999). Menurut Alwasilah (1994), pengetahuan guru tentang sastra sangat rendah; sastra diajarkan oleh guru-guru yang tidak profesional, guru tidak memahami cara mengajar sastra dengan baik (Wei,1999); guru dan strategi mengajar mereka penyebab rendahnya kualitas pengajaran sastra (Mansour,1999).

Namun, pendapat Alwasilah bahwa sastra diajarkan oleh guru-guru yang tidak profesional, bertentangan dengan penemuan Rudy (2005). Menurut Rudy (2005), sastra mampu diajar oleh semua guru bahasa karena komponen terpenting dalam apresiasi sastra adalah strategi mengajar dan mengapresiasinya. Dengan demikian, kesepakatan awal tentang guru yang menjadi masalah utama, bukan karya sastra, karena guru tidak mengetahui cara mengajar sastra dan bagaimana cara mengapresiasinya. Rendahnya penampilan mengajar guru dalam menyelenggarakan pendidikan juga disebabkan oleh rendahnya kualitas guru dalam hal penguasaan materi ajar dan keterampilan mengajar. Unesco melaporkan tingkat penguasaan bahan ajar dan keterampilan dalam menggunakan metode mengajar yang inovatif masih kurang, umumnya guru menggunakan metode ceramah. Hasil uji coba tes kompetensi, rata-rata skor untuk semua bidang studi di bawah 50\%. Untuk guru bahasa Indonesia 54\% (Direktorat Tenaga Kependidikan, 2003).

Berdasarkan permasalahan tersebut, penulis memandang kreativitas guru dalam pembelajaran sastra perlu ditingkatkan karena dengan adanya guru sastra yang kreatif diharapkan pembelajaran sastra yang terjadi benar-benar disenangi oleh para siswa. Dengan guru yang kreatif, ranah kognitif, afektif, dan psikomotor juga akan dikembangkan secara proporsional, karena pembelajaran sastra yang mengembangkan ketiga ranah tersebut memiliki peran dan fungsi yang cukup penting dalam mengembangkan kepribadian siswa. Oleh karena itu, pengembangan kompetensi guru dalam pembelajaran apresiasi sastra anak perlu ditingkatkan agar tujuan pembelajaran apresiasi sastra dapat tercapai. Berdasarkan permasalahan itu, penulis ingin menjelaskan kompetensi kognitif yang perlu dikuasai guru dalam pembelajaran apresiasi sastra di SD.

\section{Metode}

Penelitian ini menggunakan pendekatan kualitatif. Data diperoleh melalui wawancara dengan responden. Masalah-masalah yang dikemukakan pada responden dilakukan dengan wawancara semi terstruktur. Wawancara melibatkan 12 orang responden, yang terdiri dari enam orang guru inti dan enam orang dosen. 
Untuk memudahkan penyajian data, keenam guru inti tersebut diberi inisial A1, A2, A3, A4, A5, dan A6. Begitu juga dengan enam orang dosen tersebut diberi inisial B1, B2, B3, B4, B5, dan B6.

Dalam penelitian kualitatif, peneliti merupakan instrumen utama dalam pengumpulan data dan membuat analisis. Wawancara dilakukan dengan panduan garis besar pertanyaan dan alat perekam suara. Hasil rekaman dibuat dalam bentuk transkrip. Data yang telah terkumpul dianalisis dengan menggunakan pendekatan analisis kualitatif untuk mengembangkan tema-tema dan kodekode tertentu.

\section{Pembahasan}

Berikut ini dideskripsikan hasil analisis terhadap data yang diperoleh berdasarkan hasil wawancara dengan dua belas orang orang responden tersebut. Dari ranah kognitif, kompetensi yang perlu dikuasai guru dalam proses pembelajran sastra di SD adalah (1) pengetahuan tentang teori sastra, (2) metode pembelajaran sastra, dan (3) penilaian.

\section{Pengetahuan tentang Teori Sastra}

Pengetahuan tentang teori sastra diperlukan oleh mahasiswa dalam pembelajaran apresiasi sastra anak seperti diungkapkan oleh responden guru (A) dan dosen (B). Untuk mengapresiasi karya sastra secara produktif guru memerlukan teori seperti yang diungkapkan oleh responden A3 bahwa guru memerlukan materi bagaimana tata cara menulis karangan seperti cara menentukan topik dan kerangka karangan. Responden A5 menyatakan bahwa guru perlu pengetahuan tentang bagaimana menggunakan pilihan kata yang tepat dalam menulis puisi, sedangkan untuk mengapresiasireseptif guru perlu pengetahuan tentang teori seperti yang dinyatakan oleh responden A4 guru perlu menguasai unsur-unsur intrinsik untuk mengapresiasi karya sastra seperti cerita, puisi, dan pantun. Pengetahuan tentang unsur intrinsik juga diperlukan untuk memparafrse seperti yang dinyatakan oleh responden A6.

Responden B1 dan B4 menyatakan bahwa mahasiswa perlu mengetahui teori tentang sastra yaitu teori tentang puisi dan drama. Selanjutnya ia menyatakan walaupun kepada siswa SD tidak diberikan teori, tetapi guru perlu menguasainya. Pernyataan ini dipertegas oleh responden B3 dan B6 bahwa mahasiswa tidak bisa mengapresiasi sastra apabila tidak tahu teori seperti unsur-unsur intrinsik. Di samping itu, responden B3 dan B5 bahwa hakikat tentang sastra seperti pengertian, jenis dan tujuan pembelajaran penting untuk diketahui oleh mahasiswa.

\section{Metode Pembelajaran Sastra}

Metode pembelajaran adalah suatu cara atau upaya yang dilakukan oleh para pendidik agar proses belajar-mengajar pada siswa tercapai sesuai dengan tujuan. Metode pembelajaran ini sangat penting di lakukan agar proses belajar mengajar tersebut nampak menyenangkan dan tidak membuat para siswa tersebut suntuk, dan juga para siswa tersebut dapat menangkap ilmu dari tenaga pendidik dengan mudah. Seperti yang dinyatakan oleh responden A6 bahwa penggunaan metode dan strategi penting untuk mengajarkan apresiasi sastra. Pernyataan ini dperkuat oleh responden A6. Apabila guru tidak menggunakan metode dan strategi maka pembelajaran dapat membosankan siswa. Namun dalam kenyataannya masih ada guru yang belum mengetahui konsep dan langkah-langkah pembelajaran. Seperti yang dinyatakan oleh responden A4 bahwa guru penting untuk menguasai berbagai jenis metode pembelajaran dan bagaimana langkah-langkah mengajarkannya. 
Apabila guru telah menggunakan metode dalam pembelajaran, maka proses interaksi antara siswa dengan guru, siswa dengan siswa, dan siswa dengan media akan terlaksana. Seperti yang diungkapkan oleh responden A1 bahwa dalam pembelajaran apresiasi sastra guru perlu menciptakan interaksi, misalnya dengan meminta siswa merespons karya sastra. Selanjutnya responden A3 menyatakan bahwa guru perlu menguasai pembelajaran terpadu dalam pembelajaran yaitu adanya keterpaduan antara menyimak, berbicara, membaca, dan menulis.

Pentingnya metode dalam pembelajaran apresiasi sastra perlu dikuasai mahasiswa, seperti yang dinyatakan oleh responden B3, bahwa sebagai calon guru di SD, mahasiswa perlu mengetahui bagaimana cara membelajarkan sastra kepada siswanya. Selanjutnya ia menyatakan bahwa mahasiswa perlu memikirkan metode dan strategi yang cocok dengan materi sastra. Dalam pemilihan metode pembelajaran, yang penting diperhatikan oleh mahasiswa adalah bagaimana nilai yang terkandung dalam karya sastra sampai pada siswa. Hal ini sesuai dengan pernyataan yang diungkapkan oleh responden B1 dan B5 bahwa pengembangan pendidikan karakter melalui karya sastra bagus dikembangkan. Selanjutnya responden B4 memperkuat bahwa pembelajaran sastra merupakan landas tumpu untuk menanamkan nialinilai moral. Untuk mewujudkannya dosen perlu memberikan contoh pembelajaran sastra yang menarik. Menciptakan pembelajaran yang menarik misalnya dapat dilakukan dengan menggunakan media dan bercerita seperti yang dinyatakan oleh responden B1 dan B6. Di samping itu mahasiswa perlu diberi latihan-latihan dalam kegiatan bersastra seperti yang diungkapkan oleh responden B6.

\section{Penilaian}

Penilaian adalah suatu pemeriksaan terhadap pelaksanaan suatu program yang telah dilakukan dan yang akan digunakan untuk meramalkan, mengambil data, dan mengendalikan pelaksanaan program kedepannya agar jauh lebih baik. Oleh sebab itu, penilaian perlu dkuasi oleh guru untuk mengetahui tingkat penguasaan siswa terhadap pembelajaran yang telah dilaksanakan seperti yang diungkapkan oleh responden A3 guru perlu mengetahui penilaian yang dilakukan dalam membaca puisi dan apa kriteria penilaiannya. Pernyataan ini diperkuat oleh responden A4 bahwa belum semua guru memahami penilaian sastra. Selanjutnya pernyataan responden A5 dan A6 adalah guru juga perlu menguasai penilaian proses dan penilaian akhir.

Pembelajaran sastra seperti membacakan puisi atau membcakan cerita tidak hanya sekedar membacakan saja, tetapi mahasiswa perlu memperhatikan krteria yang perlu diperhatikan dal kegiata tersebut. Selanjutnya mahasiswa perlu mengetahui prosedur penilaian

\section{Pengetahuan tentang Teori Sastra}

Hasil penelitian menujukkan bahwa teori sastra perlu dikuasai mahasiswa dalam pembelajaran apresiasi sastra. Pada hakikatnya, teori sastra membahas secara rinci aspek-aspek yang terdapat di dalam karya sastra. Menurut (Yunus, 1990) teori sastra umumnya berusaha menjelaskan kepada pembaca prihal karya sastra sebagai karya seni yang menggunakan bahasa sebagai mediumnya. Perlunya pemahaman terhadap teori karena menurut (Teeuw, 1984) karya sastra mempunyai kekhasan bahasa itu menunjukkan bahwa karya sastra bukanlah komunikasi biasa, melainkan komunikasi yang unik dan dapat menimbulkan multi makna dan penafsiran. Selanjutnya, Sastrowardoyo (1988) mengungkapkan bahwa karya 
sastra merupakan ekpresi jiwa dan batin penciptanya. Oleh karena itu diperlukan seperangkat teori keilmuan yang mengkaji, membahas, memperkatakan, dan menjelaskan perihal apa, mengapa, dan bagaimana karya sastra itu.

Jika diamati cuplikan hasil wawancara, teori yang digunakan oleh guru dalam pembelajaran apresiasi sastra adalah teori struktural. Teori ini melihat sastra sebagai suatu subjek yang otonom. Sastra sebagai karya otonom terdiri dari dua unsur penting. Kedua unsur itu adalah unsur-unsur yang membangunnya dari luar dan dari dalam. Unsur itulah yang disebut unsur intrinsik dan unsur ekstrinsik. Hal itu tertera di dalam dokumen kurikulum sekolah 1975, 1984, 1987, kurikulum 1994, 2006 dan kurikulum 2013. Jadi, pada dasarnya teori strukturallah yang mewarnai teori sastra yang digunakan untuk pembelajaran di sekolah.

Unsur intrinsik adalah unsur-unsur yang membangun karya sastra itu sendiri.Unsur-unsur intrinsik tersebut adalah unsur-unsur yang (secara langsung) turut serta membangun cerita,yaitu meliputi tokoh. plot, penokohan, tema, latar, sudut pandang penceritaan, bahasa atau gaya bahasa, dan sebagainya (Nurgiyantoro, 2009).Tokoh cerita merupakan pemain, pelaku, pelakon atau orang yang berada atau yang mempunyai peranan dalam cerita tersebut. Dalam cerita fiksi, tokoh cerita tidak harus berwujud manusia, seperti anak-anak atau orang dewasa lengkap dengan nama dan wataknya, melainkan juga dapat berupa binatangatau suatu objek yang lain yang biasanya merupakan bentuk personifikasi manusia.

Oleh karena itu, tokoh cerita dapat dipahami sebagai kumpulan kualitas mental, emosional, dan sosial yang membedakan seseorang dengan orang lain (Lukens, 2003). Nurgiyantoro (2009) mengemukakan bahwa tokoh cerita dapat dipahami sebagai seseorang yang dipaparkan dalam teks cerita naratif yang oleh pembaca ditafsirkan mempunyai kualitas moral dan kecenderungan tertentu sebagaimana yang dinyatakan melalui kata-kata dan ditunjukkan dalam tindakan.

Dalam kaitannya dengan sebuah teks cerita, alur berhubungan dengan pelbagai hal seperti peristiwa, konflik yang berlaku, dan ahkirnya mencapai klimaks, serta bagaimana kisah yang diselesaikan. Alur berkaitan dengan masalah bagaimana peristiwa, tokoh, dan segala sesuatu yang digerakkan sehingga menjadi sebuah rangkaian cerita yang padu dan menarik. Alur merupakan aspek utama yang perlu dipertimbangkan, kerana aspek inilah yang menentukan menarik tidaknya cerita dan mengajak anak untuk secara total untuk mengikuti cerita.

Tema sebuah karya sastra harus diawali dengan menjelaskan tentang tokoh dan perwatakannya serta keadaan dan jalan cerita yang ada, sehingga tema boleh dikatakan sebagai gagasan pusat yang menjadi asas cerita. Nurgiyantoro (2009:80) menyatakan bahwa tema dalam sebuah cerita dapat dipahami sebagai sebuah maknayang mengikat keseluruhan isi cerita, sehingga cerita hadir sebagai satu kesatuan yang padu. Selanjutnya Lukens (2003:129) menyatakan bahawa tema juga boleh dipahami sebagai sebuah gagasan utama atau sebagai makna utama dari sebuah tulisan. Jadi dalam hal ini tema merupakan asas pengembangan sebuah cerita. Tema sebuah cerita fiksi merupakan sebuah gagasan utama atau makna utama cerita.

Latar atau setting adalah tempat terjadinya peristiwa, kapan terjadinya peristiwa, dan latar belakang kehidupan sosial-budaya masyarakat tempatpara tokoh berinteraksi dengan sesamanya. Bentuknya dapat bermacam-macam, contohnya, nama kampung, nama kota, nama daerah dan nama negara; yang dapat 
diamati dengan pancaindera kita, seperti suasana pasar malam. Biasanya latar ini muncul pada semua bahagian cerita atau penggalan cerita.Menurut Lukens (2003), dalam fiksi dewasa latar boleh berlaku di mana saja termasuk dalam benak tokoh, sehingga tidak terlalu banyak memerlukan maklumat tentang tokoh. Namun, tidak demikian halnya dalam cerita fiksi anak. Dalam cerita fiksi anak hampir semua peristiwa yang dikisahkan kejelasan tempat dan waktu kejadian, oleh karena itu memerlukan keterangan latar secara lebih detil.Kejelasan cerita tentang latar dalam banyak hal akan membantu anak memahami alur cerita.

Bahasa yang dipergunakan dalam teks sastra merupakan bagian sebuah style, yaitustylepenulisnya. Style merupakan sebuah cara mengungkapkan dalam bahasa, cara bagaimana seseorang mengungkapkan sesuatu yang akan diungkapkan atau bagaimana seorang pengarang mengungkapkan sesuatu sebagai ekspresi apa yang mau dikatakan. Menurut Lukens (2003),style pada hakikatnya adalah cara pengekspresian jatidiri seseorang, karena tiap orang akan mempunyai cara-cara tersendiri yang berbeda dengan orang lain.Style yang indah adalah style yang mampu membawakan cerita dengan sangat mengena sehingga mampu mempengaruhi pembaca dan menjadi sesuatu yang amat mengesankan. Itulah sebabnya Mitchell (2003) mendefinisikan style sebagai sesuatu yang amat mengesankan.

Sudut pandang dapat dipahami sebagai cara sebuah cerita dikisahkan. Menurut Nurgiyantoro (2009), sudut pandang merupakan suatu cara atau pandangan yang dipergunakan pengarang sebagai satu cara untuk memaparkan tokoh, tindakan, latar, dan berbagai peristiwa yang membentuk cerita dalam sebuah teks fiksi kepada pembaca. Jadi, sudut pandang pada hakikatnya adalah sebuah cara, strategi atau siasat yang secara sengaja dipilih pengarang untuk menyampaikan cerita dan gagasannya.Pemilihan sudut pandang dalam cerita fiksi akan menjejaskan kebebasan dan keobjektifan dalam bercerita

Adapun unsur-unsur intrinsik yang membangun puisi kanak-kanak adalah tema, amanat, tipografi, bunyi, citraan, irama, dan gaya bahasa.Lukens (2003) menjelaskan bahwa isi puisi adalah emosi dan mempunyai sumbangan yang signifikan bagi kehidupan. Dorongan untuk menulis puisi biasanya muncul karena penulis mempunyai pengalaman emosional yang kuat. Pada kegiatan menulis puisi anak, kehadirannya didahului oleh adanya pengalaman emosional yang menuntut untuk diungkapkan.

Jika penulis puisi itu anak-anak, kandungan isi puisi yang dihasilkan juga tidak jauh dari anak, pengalaman anak, dan bagaimana cara anak memandang hal-hal yang menurut orang dewasa tergolong sederhana. Menurut Mitchell (2003), tematema yang banyak ditemui pada puisi anak antara lain adalah masalah keluarga, persahabatan, dan lain-lain. Kandungan dalam puisi anak, antara lain berkaitan dengan dengan hal-hal yang ada di sekitar anak. Misalnya orang tua, guru, teman sepermainan, binatang kesukaan, persekitaran alam, dan lain-lain.

Amanat merupakan salah satu unsur yang membangun puisi anak-anak. Amanat dalam puisi adalah nasihat yang disampaikan oleh pengarang kepada pembaca atau pendengar. Oleh karena itu, amanat hanya boleh dirumuskan oleh pembaca atau para pecinta, sehingga terjadi perbedaan pendapat antara satu tokoh dengan tokoh lain. Perbedaan ini disebabkan karena latar belankang tokoh, baik dari sisi pengetahuan, latar agama, latar budaya, dan sebagainya. 
Tipografi adalah ukiran bentuk puisi yang biasanya berupa susunan baris, ke bawah. Ada yang menyebutkan istilah tipografi dengan sebutan tata wajah puisi. Baik tipografi maupun tata wajah mempunyai pengertian yang sama, yaitu salah satu unsur puisi yang menjadikan puisi lebih indah.

Aspek bunyi pada sebuah puisi merupakan hal yang penting, yaitu menentukan keberhasilan sebuah puisi sebagai sebuah karya seni. Puisi boleh dipandang sebagai permainan bahasa melalui pemilihan kata-kata. Aspek bunyi pada puisi akan memberi kesan kepuitisan puisi. Adanya unsur kepuitisan dalam puisi memberi semacam jaminan bahwa puisi itu indah.

Citraan atau pengimajian adalah susunan kata yang dapat menjelaskan apa yang dinyatakan oleh penyair. Mengingat puisi bukanlah hanya untuk sekadar dibaca maka penyair menggunakan citraan ini sebagai cara untuk memperjelaskan agar para pecinta memahami puisi ciptaannya melalui citraan yang disajikan dalam beberapa bentuk citraan:(1) Wawasan (visual imagery), (2) pendengaran (auditory imagery), (3) bau (smille imagery).

Gaya bahasa atau irama adalah cara khas yang dipakai penyair untuk menimbulkan kesan estetik (keindahan) pada karya sastra puisi yang dihasilkannya. Perhatikan contoh pengulangan bunyi dan pengulangan kata pada puisi ini yang menimbulkan bunyi teratur dan mencipta irama.

\section{Metode Pembelajaran Sastra}

Pembelajaran bahasa dan sastra di SD diarahkan pada kompetensi siswa untuk berbahasa dan berapresiasi sastra.. Sedangkan pembelajaran sastra, ditujukan untuk meningkatkan kemampuan siswa dalam memahami, menikmati, dan menghayati karya sastra. Pengetahuan tentang sastra digunakan sebagai penunjang dalam mengapresiasi karya sastra.. Untuk memahami, menikmati dan menghayati karya sastra siswa wajib membaca karya sastra.

Pembelajaran apresiasi sastra di SD dilaksanakan secara terpadu dengan pembelajaran bahasa baik dengan ketrampilan menulis, membaca, menyimak, maupun berbicara. Dalam praktiknya, pembelajaran sastra berupa pengembangan kemampuan menulis sastra, membaca sastra, menyimak sastra, dan berbicara sastra. Oleh sebab itu pembelajaran sastra mencakup mendengarkan dan merefleksikan pembacaan puisi, dongeng, pementasan drama. Membaca karya sastra dan memahami maknanya, baik terhadap karya sastra yang berbentuk puisi, prosa, maupun naskah drama. Menulis puisi, menulis cerita, menulis drama. Berbalas pantun, deklamasi, mendongeng, bermain peran, menceritakan kembali isi karya sastra.

Berdasarkan hal tersebut, kegiatan mengapresiasi karya sastra dapat dilakukan secara langsung, artinya siswa harus secara langsung membaca bermacam sajak, cerita, atau drama dari berbagai sastrawan atau secara langsung mendengarkan sajak dideklamasikan atau dibacakan dan menyaksikan drama yang dipentaskan. Hal itu dimaksudkan agar siswa memperoIeh pemahaman yang sebaik-baiknya tentang wujud karya sastra dan dapat menghargainya secara wajar. Kegiatan tersebut, seperti membaca, mendengar, menyaksikan, harus dilakukan secara sungguh-sungguh.

Selanjutnya kegiatan apresiasi dapat dilakukan secara tidak langsung. Sesudah siswa berdialog langsung, dan mendalami karya sastra, mengenal, memahami, menganalisis, menghayati, mereka diperkuat dengan pengetahuan tentang sastra. Selain itu, dua kegiatan lagi sebagai pelengkap, yaitu kegiatan dokumentasi dan 
kegiatan kreatif. Kegiatan dokumentasi berupa kegiatan mengumpulkan dan menyusun buku-buku dan majalah-majalah sastra, membuat kliping, dan sebagainya, sedangkan kegiatan kreatif berupa kegiatan belajar atau berlatih menciptakan sendiri puisi, cerita, atau drama.

Berdasarkan pendapat di atas dapat disimpulkan bahwa proses pembelajaran sastra perlu melibatkan guru sastra, pihak yang mengajarkan sastra, dan siswa, subjek yang belajar sastra. Usaha yang bisa dilakukan agar siswa dapat belajar sastra dengan efektif adalah menggunakan metode pembelajaran sastra. Metode merupakan suatu cara yang dalam fungsinya adalah alat untuk mencapai tujuan. Semakin baik metode maka semakin efektif pula pencapaian tujuannya. Menurut Surakhmad (1980:75), metode merupakan suatu cara yang dalam fungsinya adalah alat untuk mencapai tujuan. Semakin baik metode maka semakin efektif pula pencapaian tujuannya. Metode yaitu rencana keseluruhan dalam menyajikan materi bahasa secara teratur (Anthony,1972; Baradja, 1985). Dalam suatu pendekatan akan terdapat beberapa metode.

\section{Penilaian}

Penilaian dalam proses pembelajaran dilakukan oleh guru sebagai bagian integral dari pembelajaran itu sendiri. Artinya, penilaian tidak dapat dipisahkan dari penyusunan dan pelaksanaan pembelajaran. Proses penilaian mencakup pengumpulan bukti yang menunjukkan pencapaian belajar siswa. Menurut Griffin dan Nix (1991), penilaian merupakan suatu pernyataan berdasarkan sejumlah fakta untuk menjelaskan karakteristik seseorang atau sesuatu. Selain itu, menurut Sunarti (2014), penilaian diartikan sebagai kegiatan menafsirkan data hasil pengukuran atau kegiatan untuk memperoleh informasi. $\begin{array}{rrr}\text { Kurikulum } & \text { KTSP dan Kurikulum } \\ 2013 & \text { menyarankan penggunaan } \\ \text { pendekatan } & \text { kontekstual dalam }\end{array}$

pembelajaran. Penggunaan pendekatan pembelajaran itu mengharuskan guru untuk menggunakan penilaian otentik dalaml mengukur hasil belajar siswa. Menurut Stiggins (dalam Mueller, 2008), penilaian otentik merupakan penilaian kinerja (performansi) yang meminta siswa untuk mendemonstrsikan keterampilan dan kompetensi tertentu yang merupakan penerapan pengetahuan yang dikuasainya. Berdasarkan pengertian tersebut, penilaian otentik merupakan penilaian terhadap tugas-tugas yang dilakukan siswa sesuai dengan kenyataan di dunia nyata. Tujuan penilaian itu adalah untuk mengukur berbagai keterampilan dalam berbagai konteks yang mencerminkan situasi di dunia nyata dimana keterampilanketerampilan tersebut digunakan.

Misalnya siswa ditugaskan untuk menulis topik-topik tertentu seperti dalam kehidupan nyata, berpartisipasi dalam diskusi, menulis surat. Dalam kegiatan itu, baik materi pembelajaran maupun penilaiannya terlihat atau bahkan alamiah. Jadi, penilaian ini menekankan pada pengukuran kinerja, melakukan sesuatu yang merupakan penerapan ilmu pengetahuan yang telah dikuasai secara teoritis. Salah satu contoh yaitu KD 4.4 menyampaikan teks cerita diri personal tentang keluarga secara mandiri dalam bahasa Indonesia lisan dan tulis yang dapat diisi dengan kosakata bahasa daerah untuk membantu penyajian. Indikatornya menceritakan kembali isi teks. Rubrik penilaian untuk indikator tersebut adalah keruntutan pengungkapan isi teks, kelancaran dan kewajaran, ketepatan diksi.
Simpulan 
Kompetensi yang diperlukan oleh guru dalam mengapresiasi karya sastra pada mata pelajaran bahasa Indonesia harus dikuasi oleh guru di SD. Penguasaan tersebut penting agar pembelajaran yang dilaksanakan dapat mencapai tujuan yang diharapkan. Tujuan tersebut adalah mendorong tumbuhnya sikap apresiatif terhadap karya sastra yaitu sikap menghargai dan mencintai karya sastra.

Oleh sebab itu, kompetensi yang perlu dikuasai guru dalam mengapresiasi sastra di SD adalah (1) pengetahuan tentang teori sastra, (2) metode pembelajaran sastra (3) penilaian. Pemahaman guru tentang teori sastra perlu ditingkatkan. Guru juga perlu menguasai metode pembelajaran, agar dapat melaksanakan pembelajaran yang menyenangkan. Penilaian pembelajaran perlu dikuasai untuk memperoleh informasi tentang pencapaian belajar siswa.

\section{Daftar Rujukan}

Alwasilah, A. Chaedar.1999. "Literature Deserves a Place in Our School Lesson". The Jakarta Post, June 18.

Anthony, Edward M. 1972. "Approach, Method, and Technique" dalam Allen \& Campbell, ed., Teaching English as a Second Language: A Book of Readings. New York: McGrawHill.

Baradja, M.F. 1985. "A Way to Analyze Method". Makalah. Semarang: Akademi Bahasa 17 Agustus 1945. Direktorat Tenaga Kependidikan, Dirjen Dikdasmen. 2003. Standar Kompetensi Guru. Jakarta: Depdiknas.

Effendi, S. 1984. Bimbingan Apresiasi Puisi. Jakarta: Tangga Mustika Alam.
Griffin, P., \&Nix, P.1991.Educational Assessment and Reporting: A NewApproach. Sydney: Harcourt Brace JovanovichPublishers.

Huck, C., Hepler, S., \&Hicman, J. 1987.Children's Literature in The Elementary School. Chicago: Rand McNally College Company.

Ismail, Taufik. 2000. "Pengajaran Sastra yang Efektif dan Efisien di SLTA", Widyaparwa Nomor 54. Yogyakarta: Balai Bahasa.

Kementerian Pendidikan Nasional. 2012. "Hasil Uji Kompetensi Guru". Jakarta.

Kinayati. 2006. Analisis Teks Sastra dan Pengajarannya. Yogyakarta: Pustaka.

Lukens, R. J. 2003. A Critical Handbook of Children Literature. Boston: Allyn and Bacon.

Mansour,

Wisam.1999.

"ApreciatingPoetry". English

Teaching Forum.Vol.37/4

Mitchell, W. 2003, "Designing the Learning Space".Campus Technologyhttp://www.campuste chnology/article. aspx ?aid=3946.

Mueller, John. 2008. "Authentic Assessment Toolbox". North Central College http://www. noctrl.edu/,Napervill

e,http://jonathan.mueller.faculty.noctrl.edu/ toolbox/ index.htm (Diunduh 25 November 2014).

Nurgiyantoro, Burhan. 2009. PenilaiandalamPengajaranBaha sadanSastra. Yogyakarta: BPFE.

Rudy, Rita Inderawati. 2005. "Keefektifan Model Respons Pembaca dan Simbol Visual dalam Pembelajaran Sastra di SD." Makalah. Dipresentasikan dalam Konferensi Internasional 
Himpunan Sarjana Kesusasteraan

Indonesia (HISKI) XVI di

Palembang, 18-21 Agustus 2005.

Rusyana,

Yus.

2002.

"KurikulumBahasadanSastradala

mGamitanKurikulumBerbasisKo

mpetensi." Makalah yang

disajikanpada Seminar

NasionalMenyongsongKurikulum

Bahasa Indonesia

BerbasisKompetensi:

PeluangdanTantangan di UPI

Bandung.

Sastrowardoyo, Subagio. 1988.

MencariJejakTeoriSatraSendiri

(RenunganSeorangAwam),

dalamMursalEsten.

MenjelangTeoridanKritikSusaster

a Indonesia yang Relevan.

Bandung: Angkasa.

Surakhmad, Winarno. 1980.

MetodologiPengajaranNasional.

Bandung: Jemmars.

Sunarti. 2014. Penilaian dalam Kurikulum

2013. Yogyakarta: Penerbit Andi.

Teeuw,

A.

1984.MembacadanMenilaiSastra.

Jakarta: Penerbit PT Gramedia.

Yunus, Umar. 1990.

TiadaBermimpiLagidanSerangkai anTulisantentangSastera.Pekanba ru: UNRI Press.

Wei, Shu. 1999. "Literature Teaching." English Teaching Forum. Vol. $37 / 3$. 